\title{
Analiza verbalne komunikacije i usporedba pobjedničkih govora posljednja tri predsjednika Republike Hrvatske
}

STANA ODAK KRASIĆ

Sveučilište VERN', Zagreb

VALENTINA PAVLOVIĆ

Sveučilište VERN', Zagreb

\section{SAŽETAK}

Javni govor državnika oduvijek je fokus analize i tema razmišljanja stručnjaka, ali i medija i građana, pogotovo ako se radi o javnoj komunikaciji najviših državnih instanci. Moderno govorništvo i teorije javne komunikacije u konstantnoj su promjeni, a nove tehnologije rapidno ih vode $\mathrm{k}$ oplemenjivanju novitetima, no i $\mathrm{k}$ njegovanju već ustaljenih standarda. Analiza verbalne komunikacije predsjednika država često je srž istraživanja te se u njima nastoje uspostaviti otkloni i prakticiranja standarda i preporuka, dok se u komparativnim analizama nastoje uvidjeti distinkcije i sličnosti govora na tim funkcijama. Upravo je predmet ovoga rada analiza verbalne komunikacije pobjedničkih govora posljednja tri predsjednika Republike Hrvatske, a cilj mu je komparacija i analiza sadržaja govora. Analizama je zaključeno da postoje otkloni i nedostaci svakog pojedinog govora, no ne u svim stavkama, ali i prednosti svakog govornika te vještine i znanja implementirani u realizaciju govora.

Ključne riječi: analiza, verbalna komunikacija, predsjednik Republike Hrvatske, pobjednički govor 


\section{Uvod}

Godine 1992. izabran je prvi hrvatski predsjednik te je od tada do danas Republika Hrvatska dobila ukupno četiri predsjednika i jednu predsjednicu. Tematika govora predsjednika unutar političke kampanje, njegov diskurs kao kandidata, a potom i kao novoizabranog predsjednika, imaju važnu ulogu $\mathrm{u}$ analizi i predviđanjima njegovih poteza tijekom mandata.

Ovaj rad sastoji se od dva dijela, teorijskog i praktičnog. Za teorijski dio rada korištena su slična istraživanja stručnjaka u Hrvatskoj, znanstveni članci koji se bave analizom političkih govora i govora općenito te udžbenici i priručnici vezani za verbalnu i javnu komunikaciju. Važno je napomenuti kako najveća vrijednost ovoga rada i samog istraživanja leži u činjenici da do sada nije rađena analiza pobjedničkih govora hrvatskih predsjednika. Za potrebu analize autorice su se vodile Škarićevom trodiobom stilova govora na jednostavni, umjereni i visoki stil, s naglaskom na posljednji koji podrazumijeva svečane prigodne govore, zdravice, pozdravne govore i nekrologe (Škarić, 2000). Jedna od glavnih vrsta prigodnih govora svakako su inauguracijski govori, koji su bili tema brojnih istraživanja, dok su do sada u potpunosti bili zanemareni pobjednički govori predsjednika.

Praktični, odnosno istraživački dio rada proveden je kvalitativnom analizom sadržajai komparativnom analizom kojom su analizirana tri pobjednička govora posljednja tri izabrana predsjednika Republike Hrvatske. U istraživačkom dijelu rada nastojalo se doći do razlika i sličnosti pobjedničkih govora i minuciozno analizirati verbalnu komunikaciju. Kvalitativnom analizom sadržaja analizirana su tri govora, govor Ive Josipovića, održan 10. siječnja 2010. u Hrvatskom novinarskom domu, u trajanju od 8 minuta i 20 sekundi, govor Kolinde Grabar-Kitarović, održan 11. siječnja 2015. u stožeru HDZ-a, u trajanju od 9 minuta i govor Zorana Milanovića, održan 11. siječnja 2020. u Tvornici kulture, u trajanju od 9 minuta i 5 sekundi. Govori su sveukupno trajali 26 minuta i 25 sekundi i snimljeni su. Analiza je pokazala kako se sva tri govora uvelike razlikuju te da u svakom govoru postoji nedostatak.

\section{Teorijska određenja ključnih pojmova}

Prema Aniću (2006) verbalna komunikacija podrazumijeva verbalni jezik koji označava interpersonalni odnos izražen riječima. Javna komunikacija nije isto što i persuazija (Tomić, i sur., 2020), već označava pokušaj smanjivanja razlike u onom što takva komunikacija čini od onoga što subjekti (sudionici) te komunikacije očekuju, objašnjava Heath (2005 prema Tomić i sur., 2020). Javni nastupi su aktivnosti kod kojih je verbalno u suglasju s neverbalnim i teži uzajamnom odnosu na relaciji govornik - publika, kako bi se govornik identificirao s publikom te istovremeno publika identificirala s govornikom (Čerepinko, 2011), jer govornik formira samo polovicu govora, dok drugu polovicu oblikuje slušatelj (Škarić, 2000).

Aristotel je uočio da su svi ljudi pozvani, gotovo svaki dan, uvjeravati druge ljude (Borg, 2010). U situacijama uvjeravanja cilj je bio da slušatelj krene od točke A do točke B, odnosno od polazišta do nekog određenog cilja, a upravo to mijenjanje gledišta nazvano je uvjeravanje. Postoje tri različita tipa uvjeravanja, prikazana u tablici 1. radi lakšeg razumijevanja i tumačenja. 
Tablica 1. Definiranje i objašnjenje ključnih pojmova osnovnih tipova uvjeravanja

\begin{tabular}{c|l} 
Ethos & $\begin{array}{l}\text { Etos (etički) odnosi se na samog govornika i karakter, odnosno na pouzdanost } \\
\text { koja iz njega proizlazi. Etos ili izvorno povjerenje odnosi se na iskrenost } \\
\text { pojedinca. }\end{array}$ \\
\hline Pathos & $\begin{array}{l}\text { Patos (čuvstven, patetičan) odnosi se na emocije publike te posjedovanje } \\
\text { empatije. }\end{array}$ \\
\hline Logos & $\begin{array}{l}\text { Logos (logičan) odnosi se na uvjeravanje s naglaskom na argumente - } \\
\text { izabrane riječi, citate, činjenice. }\end{array}$
\end{tabular}

Izvor: prilagodile autorice rada prema Borg (2010)

Govor je sustav ostvaraja jezika (Pavličević Franić, 2008) i Škarić i Varošanec-Škarić (1994) navode da je sažet opis govornikova statusa sadržan u govornim sposobnostima koje se tiču govornoakustične realizacije, jezičnoga i pravogovornog umijeća, općenitih govorničkih sposobnosti i komunikacijske uspješnosti, a upravo ta uspješnost ovisi o psihološkim i sociološkim čimbenicima (Stančić i Ljubešić, 1994 prema Pavličević Franić, 2008). Jezici se međusobno razlikuju u načinu korištenja varijacija tona. U tom smislu razlikuju se tri osnovne kategorije jezika: tzv. intonacijski jezici, jezici akcenatske prozodije i tonski jezici. U prozodijska obilježja ${ }^{1}$ ubrajaju se naglasak ili/i akcent, ritam, intonacija te varijacije u brzini i glasnoći govora, kadšto i trajanje emisije fonema (kvantiteta). Iako ima univerzalnih zakonitosti u vezi s prozodijom, uporaba prozodijskih značajki uvelike je svojstvena pojedinim jezicima. S tim u skladu govori se o prozodijskoj tipologiji, koja obuhvaća tonsku i ritmičku tipologiju.

Publika i poruka sastavnice su javnog govora i njegovi važni objekti. Publika je element koji je važno prethodno analizirati kako bi se postiglo takozvano poistovjećivanje (Tomić i sur., 2020). Poistovjećivanje je proces u kojem govornik nastoji povezati svoje stavove sa stavovima publike kroz isticanje ciljeva, iskustva i vrijednosti (Lucas, 2015).

Jedan od najvažnijih dijelova govornih sredstava je glas (fonacija) koji ima svoje šire i uže značenje. Glas u užem smislu riječi predstavlja glasovne osobine onoga koji govori, a te osobine su ton, boja i spektralni sastav glasa koji, ponovno, ovisi o radu glasnica te prolazima unutar govornog aparata (Škarić i Varošanec-Škarić, 1994), a iz glasa dobivamo brojne informacije o govorniku, pogotovo kada se radi o biološkom, psihološkom pa i društvenom aspektu (Varošanec-Škarić, 2010 prema Biočina, 2015). Elementi glasa su fonogeničnost i disfonija, nosnost, blještavost, hiperkinetičnost i visina glasa (Škarić i Varošanec Škarić, 1994).

Jednostavnu, no vrlo jasnu i dostatnu definiciju političke komunikacije dao je Brian McNair: „svrhovita komunikacija o politici." (McNair 2003, str. 12). Politički javni nastupi u središtu su brojnih znanstvenih istraživanja, no kako navodi Borčić (2009 i 2010) nisu samo referencijalni, svrhoviti i informativni, nego su prije svega usmjereni na to da ih šarolika javnost razumije, percipira i doživi. U svome govoru političar mora pokazati stručnost, osobnost, odlučnost, ali i duhovitost. Način govora određuje političara i njegov imidž. Putem njega on ostvaruje svoje ciljeve, dobiva izbore, uspostavlja odnose i slično (Kišiček, Stanković 2014: 9-10). I, svakako najvažnije, govornik mora uvjeriti publiku da ima dobre namjere kako bi stekao njihovo povjerenje (Kišiček i Stanković, 2014). Upravo u ovom kontekstu političke komunikacije, koja nije sama sebi svrha i cilj, analizirani su pobjednički govori odabranih političara.

1 Hrvatska enciklopedija, mrežno izdanje. Leksikografski zavod Miroslav Krleža, 2021. http://www.enciklopedija.hr/Natuknica. aspx?ID=50815 (29. 11. 2021) 


\subsection{Retorički dizajn}

Retorički dizajn bio bi tekstualni dio govorene poruke, koji podrazumijeva vještinu dolaženja do teme, materijala i tekstualnog oblikovanja, a dijelove retoričkog dizajna koji se proučavaju predstavljaju dužina rečenice, izbor riječi, potkrjepe, jezične pogreške, stilska elegancija i govorni bonton (Škarić i Varošanec-Škarić, 1994).

Unutar retoričkog dizajna mjeri se učestalost modalnih izraza i retoričkih figura. Modalni su izrazi kratki komentari koje govornik izgovara. Oni su stereotipni pa tako predstavljaju i svojevrsne „okamine“ (Škarić, 2000). Figure u retorici odlika su elokucije (Škarić, 1995) koja označava samu vještinu izlaganja, ali i izražavanja (Anić, 2006), a faza elokucije (elocutio) (Škarić, 1995) faza je pripreme govora koja je nadahnuta gotovo glumačkom izvedbom. Škarić (2000) je uspostavio vrste retoričkih figura: logičke figure koje konstruiraju tok misli, tropi koji su izrazi prenesenog značenja, figure misli u kojima misao nema doslovan izričaj, figure riječi kao gradacijske figure, sintaktičke figure kao konstrukcijske figure i morfološke, tvorbene i leksičke figure.

Tablica 2. Tumačenja odabranih retoričkih figura

Logičke figure su figure koje konstruiraju tok misli i koje bi trebale imati posljedicu objektivnog razumijevanja poruke. Logičke figure su: najava teme, smještaj teme, razdioba, dihotomija, tvrdnja, proširenje tvrdnje, paradoks,

Logičke figure primjer, definicija, distinkcija, popravljanje, sjedinjenje, objašnjenje, dokaz, silogizam, entimen, sorit, analogija, indukcija, dilema, konglobacija, podatak, podatak uz navođenje izvora, pogled s druge strane, pobijanje, antiparastaza, odbijanje, zaključak i sažetak.

Tropi bi bili izrazi prenesenoga značenja koji se prikazuju slikovito, a njihova formalna oznaka je prijevod u njihovo pravo značenje koje i shvaćamo onda kada govornik prenese poruku u tropima. Tropi su: metafora, personifikacija, katakreza, usporedba, epska usporedba, metonimija, sinegdoha, alegorija, simbol, amblem, perifraza, sinatroizam, antonomazija, aluzija, eufemizam, Tropi onomatopeja, epitet.

Metafora je najčešće korištena i najživlja figura, a pretpostavlja preneseno značenje, odnosno značenje koje nije izrečeno, ali je zamišljeno i publika ga razumije. Učestali trop političkog diskursa je, uz metaforu i metonimiju, i sinegdoha (prema Kišiček, 2015), koja je podvrsta metonimije. 
Figure misli su rečenice u kojima misao nema doslovan izričaj, ali znakovi u govoru ili tekstu pomažu u shvaćanje značenja i odnose se na širu sliku rečenoga i idejnu konturu. Figure misli su retorička pitanja, eksklamacija, apostrof, komunikacija, sermonicija, prozopeja, ironija, antifraza, asteizam, sarkazam, parodija, parafraza, litota, metalepsa, emfaza, hipalaga, sentencija, poslovica, epifonem, anegdota, dosjetka, parabola, pretericija, prekid, Figure misli

Figure riječi epifraza, koncesija, prolepsa, odlaganje, kolebanje, retorička skromnost, digresija, umetanje, hipotipoza, nabrajanje, kumulacija, amplifikacija, gradacija, antiklimaks, antiteza riječi, antiteza rečenica, epitrokazam, oksimoron, antimetabola, korekcija i slavenska antiteza. U javnom govoru često se koristi retoričko pitanje kao pitanje nečeg što je već svima poznato i odgovor nije potreban, a učinkovito je jer se tako obraća pozornost na dio govora i pokušava se privući slušateljev fokus na svrhu onoga o čemu govornik govori.

Figure riječi su gradacijske figure, odnosno figure koje se stvaraju s odnosom dvije riječi kako bi se stvorio pojam ili dodala vrijednost izraza. One su: ponavljanje, anafora, epifora, simploka, anadiploza, regresija, poliptoton, epanalepsa, etimološka figura, antanaklasa, sinonimija, pleonazam, retorička opširnost, brahilogija, rima, asonancija, aliteracija, homoteleut, apofonija, atelaža i igra riječima. U političkoj retorici figure riječi su učestale, a jedne od najomiljenijih su ponavljanje, anafora i epifora, kao i simploka, sinonimija i pleonazam te igra riječima.

Sintaktičke figure su figure konstrukcije i dikcije, odstupanja od uobičajenog ili standardiziranog redoslijeda riječi, dijelova riječi u rečenici ili odstupanja u slaganju rečenica. One su: izmjena redoslijeda riječi, inverzija, hiperbaton, Sintaktičke figure hipotaksa, parataksa, asindeton, polisindeton, paralelizam, vezivanje, elipsa, upravni govor i zeugma. Politički govornici upotrebljavaju inverziju, asindeton, upravni govor, a rijetko biraju izmjenu redoslijeda u rečenici osim ako se ne radi o improviziranom govoru. Inverzija je jasno sintaktička figura gdje se zavisna rečenica stavlja na prvo mjesto, prije glavne rečenice.

Morfološke, tvorbene i leksičke figure su odstupanja koja se tiču iznimki unutar tvorbe riječi i morfologije te leksika. Većinu takvih slučajeva službeni tekstovi ne bi trpjeli jer se ne radi o standardu, no u retorici je dopušteno jer

Morfološke, tvorbene i leksičke figure se radi o poetskom izrazu. Sintaktičke figure su: figure padeža, figure odnosa ja - ti, figure glagolskim oblicima, tvorbene figure i leksičke figure. Tvorbene figure je potpuno nemoguće nabrojati jer ovise o govorniku koji ih može u tom trenutku izmisliti, no ono što se obično radi je gomilanje tvorbenih morfema, korištenje nepreglednih augmentativa i deminutiva bez posebnog značenja i sl.

Izvor: prilagodile autorice rada prema Škarić (2000), Kišiček (2015) i Bagić (2012) 


\subsection{Argumentacija}

Moderna retorika je retorika gdje god postoji publika/slušatelj i ne odnosi se samo na interpersonalnu komunikaciju, već i na osobno promišljanje u kojem se ispituju argumenti (Perelman, 1959 prema Biočina, 2015) i gdje se tekst oblikuje razumski (Škarić i Varošanec-Škarić, 1994).

Unutar argumentiranog govora često postoje argumentacijske pogreške koje predstavljaju pogreške u zaključivanju (Biočina, 2015), otklon od tvrdnje (Škarić, 2000) ili lažni argumenti (Škarić, 2011), koji izgledaju poput valjanoga, ali to zapravo nisu (Hamblin, 1970 prema Kišiček, 2010). Prema analizi Kišiček i Stanković (2014) najčešće argumentacijske pogreške hrvatskih političara su ad populum, ad hominem, ad baculum, ad misericordiam, non-sequitur, generalizacija iz nepotpune informacije i zanemarivanje alternativa. Škarić (2011) je popisao sve argumentacijske pogreške: petitio principi, argumentum ad ignoratium, sekvencijalna pogreška, prenagla generalizacija, argumentum ad personam, argumentum ad hominem, pozivanje na autoritet, argumentum ad populum, generička pogreška, argumentum ad utile, argumentum ad baculum, argumentum ad auditores, etiketiranje, argument ad misericordium.

Tablica 3. Tumačenja odabranih argumentacijskih pogrešaka

\begin{tabular}{|c|c|}
\hline $\begin{array}{l}\text { Argumentum ad } \\
\text { absurdum }\end{array}$ & $\begin{array}{l}\text { - svođenje na besmisleno (najčešće - ruganjem) } \\
\text { - tvrdnja se zasniva na promicanju tvrdnje apsurdnosti, odnosno } \\
\text { besmislenosti }\end{array}$ \\
\hline $\begin{array}{l}\text { Argumentum ad } \\
\text { populum }\end{array}$ & $\begin{array}{l}\text { - dokaz koji se ne oslanja na činjenice i razloge } \\
\text { - ulagivanje i laskanje publici }\end{array}$ \\
\hline $\begin{array}{l}\text { Argumentum ad } \\
\text { passiones }\end{array}$ & - poziv na emocije \\
\hline $\begin{array}{l}\text { Argumentum ad } \\
\text { utile }\end{array}$ & - argument obećavanjem \\
\hline Petitio principi & $\begin{array}{l}\text { - cirkularan silogizam čiji sudovi ne potkrepljuju jedan drugoga, odnosno } \\
\text { nema tvrdnje ni logičke veze }\end{array}$ \\
\hline $\begin{array}{l}\text { Argumentum ad } \\
\text { misericordium }\end{array}$ & - poziv na samilost \\
\hline $\begin{array}{l}\text { Argumentum ad } \\
\text { baculum }\end{array}$ & $\begin{array}{l}\text { - argument prijetnjom („batinom“) } \\
\text { - ovaj “argument” sastoji se u tome što, u nemogućnosti drugačijeg } \\
\text { dokazivanja svoje tvrdnje - prijetimo silom, ili čak i direktno } \\
\text { upotrebljavamo silu protiv onog tko se ne slaže s našom tezom }\end{array}$ \\
\hline
\end{tabular}

Izvor: prilagodile autorice rada prema Škarić (2011)

U govoru se razlikuje afektivni i poetski izraz koji potkrepljuju i dizajn i argumentaciju. Afektivni izraz bio bi sveukupan raspon osjećajnih doživljaja (Anić, 2006), odnosno simptom i znak poremećaja sklada u biću (Škarić, 1998), te je ujedno i ekspresivni i impresivni izraz (Škarić, 2000). 


\section{Metodologija pisanja rada, hipoteze i ciljevi}

Za potrebe pisanja rada provedeno je autorsko kvalitativno i kvantitativno istraživanje verbalne komunikacije, a predmet ovoga istraživanja bila je analiza i usporedba verbalne komunikacije pobjedničkih govora posljednja tri predsjednika Republike Hrvatske: Ive Josipovića, Kolinde Grabar-Kitarović i Zorana Milanovića. Radi istraživanja korišteno je kvalitativno istraživanje analize sadržaja uz kvantitativno istraživanje koje se temelji na učestalosti pojavljivanja određenih faktora.

Prije istraživanja postavljene su tri hipoteze: H1; Prozodija neće biti krucijalan dio govorne izvedbe u sva tri govora; H2: Svaki govornik koristit će minimalno dvije retoričke figure osim metafore i H3: Svaki će govornik imati minimalno dvije argumentacijske pogreške.

Analizirana su tri govora: pobjednički govor Ive Josipovića održan 10. siječnja 2010. u Hrvatskom novinarskom domu, u trajanju od 8 minuta i 20 sekundi $^{2}$, pobjednički govor Kolinde GrabarKitarović održan 11. siječnja 2015. u stožeru HDZ-a, u trajanju od 9 minuta $^{3}$ i pobjednički govor Zorana Milanovića održan 11. siječnja 2020. u Tvornici kulture, u trajanju od 9 minuta i 5 sekundi ${ }^{4}$. Sveukupno trajanje govora bilo je 26 minuta i 25 sekundi.

\section{Rezultati istraživanja}

U radu je analizirana najprije govorna izvedba kroz parametre ustanovljene prema fonetskoj, fonološkoj analizi, analizi glasa i analizi govora, a potom i retorički dizajn u kojem je istražena dužina rečenice, tempo, ritmičnost, stil, izbor riječi, način govora (poetsko ili afektirano), vokabular i postojanje ili količina retoričkih figura. Posljednja stavka istražene verbalne komunikacije je argumentacija i argumentacijske pogreške te građenje vjerodostojnosti.

\subsection{Rezultati govorne izvedbe}

Analizom je utvrđeno kako Ivo Josipović ima statičnu boju glasa, kako mu je glas lagano povišen i poprilično odudara od fonogeničnoga glasa (glas koji ima poželjne osobine poput pouzdanosti i estetičnosti). Također, u realizaciji glasa čuje se lagana nosnost koja je posljedica napetosti grkljana i fonacijski nije ugodna, a može stvoriti dojam ukočenosti. Naglasci su dobri, govorio je pravogovorno, iako se dogodilo da mu samoglasnici imaju nedostatan izgovor (tr'nucima - trenucima) odnosno ne čuje ih se dovoljno jako. Takav gubitak samoglasnika može se pripisati i adrenalinu, unatoč vrlo mirnom načinu govora koji je očito kontroliran. Kada je riječ o suglasnicima, njihov izgovor je jasan osim ponekad mekanijeg glasa „s“ pa je tako „“ koji se asimilirao s glasom „Ž“ u riječi „stožer“ zazvučao kao „štožer“. Glas općenito zvuči ljenije i monotonije, na trenutke i nedovoljno glasno, unatoč ozvučenosti, što se opet može pripisati publici koja je glasna. Slijedi tablica o prozodijskim (naglasnim) pogreškama Ive Josipovića unutar govora:

Pobjednički govor Ive Josipovića https://www.youtube.com/watch?v=J3If-1VE-hI (30.4.2021)

Pobjednički govor Kolinde Grabar-Kitarović https://www.youtube.com/watch?v=1rrfMS5bYCg (30.4.2021)

Pobjednički govor Zorana Milanovića https://www.youtube.com/watch?v=2QluZ5MW6uE (30.4.2021) 
Tablica 4. Prozodijske pogreške Ive Josipovića

\begin{tabular}{c|c|c}
\multicolumn{3}{|c|}{ Ivo Josipović } \\
Izgovoreno & Pravilno & Min. \\
\hline tëmeljiti & temèljiti & $00: 6,47$
\end{tabular}

Izvor: izradile autorice rada

U Tablici 4. vidljivo je da je naglasni sustav unutar govora Ive Josipovića gotovo nepogrešiv. Jedina osjetno značajna pogreška bila je u glagolu „temeljiti“ kao nesvršenom glagolu u značenju gradnje nekog temelja i to u šestoj minuti govora. Ipak, u trenutku zahvale kada navodi imena kolega koji su mu pomogli tijekom kandidature i kampanje proziva i kolegu Miranda Mrsića, predsjednika izbornog stožera, te griješi tako da umjesto standardnoga govora „gdje si?" koristi „Mirando, di si?“ no takve su pogreške zanemarive jer se ta rečenica smatra ubačenom i nije dio zamišljenoga govora.

Kolinda Grabar-Kitarović ima, također, statičnu boju glasa koja nosi osobinu izražene blještavosti. Glas joj je lagano povišen, što je i posljedica vikanja. Glas je zdrav, pomalo fonogeničan, iako puca na pojedinim dijelovima što, ponovno, može biti posljedica vikanja i uzbuđenja. Dikcija je prejaka i napeta, glasovi koji su napeti su „s“ i „““. Ukupan dojam je da je glas govora preizražajan. Javlja se sinkopiranje, posljedica neurbanog govora, gubi se samoglasnik „i' (seljac’ma - seljacima, težac’ma - težacima). Prisutno je i krivo naglašavanje koje može ponovno biti posljedica neurbanog govora. Logičko isticanje unutar rečenice često je i glasnije, što vuče prema afektiranosti. Popis prozodijskih (naglasnih) pogrešaka govora Kolinde Grabar-Kitarović prikazan je u tablici:

Tablica 5. Prozodijske pogreške Kolinde Grabar-Kitarović

\begin{tabular}{c|c|c}
\multicolumn{2}{c}{ Kolinda Grabar-Kitarović } \\
Izgovoreno & Pravilno & Min. \\
\hline izâći & izaći & $00: 6,00$ \\
\hline töliko & toliko & $00: 6,52$ \\
\hline srétala & srëtala & $00: 8,42$
\end{tabular}

Izvor: izradile autorice rada

U Tablici 5. vidljive su tri naglasne pogreške tijekom šeste i osme minute govora koje, također, nisu značajne niti posebno privlače pozornost. Sve tri pogreške mogu se pripisati i brzini i neurbanom govoru koji može biti vezan uz zavičajno podrijetlo Grabar-Kitarović. Sama pogreška „izâći“ umjesto „ìzaći“ vuče na naglašavanje koje je karakteristično za područje Rijeke, gdje je i predsjednica završila osnovnu školu.

Zoran Milanović u pobjedničkom govoru predstavlja primjer dinamične boje glasa, a glas je lagano hrapav, no ipak donekle izbalansiran pa samim time i prihvatljiv. U dužim rečenicama glas poprima i karakteristike šuma, a grkljan je čujno napet. Visina glasa je srednje duboka, a na početku novih rečenica i nakon što se završila duža rečenica, ima veću visinu, vjerojatno zbog stanke među rečenicama i novog udaha. Kada je riječ o prozodiji, govor nema nekih krucijalnih pogrešaka, ali je svaka pogreška čujna jer je u kratkom vremenskom razmaku. Slijedi tablični prikaz prozodijskih pogrešaka Zorana Milanovića: 
Tablica 6. Prozodijske pogreške Zorana Milanovića

\begin{tabular}{c|c|c} 
Izgovoreno & Pravilno & Min. \\
\hline premálo & premälo & $00: 3,00$ \\
\hline od méne & od mëne & $00: 3,10$ \\
\hline dijalóg & dijàlog & $00: 3,35$ \\
\hline familija & fàmilija & $00: 3,40$ \\
\hline projèkt & pròjekt & $00: 5,03$
\end{tabular}

Izvor: izradile autorice rada

U Tablici 6. vidljivo je da je izgovorenih krivih naglasaka pet od kojih su četiri tijekom treće minute, a posljednji je u petoj minuti govora i svaki je naglasak zapravo posljedica zagrebačkog urbanog govora. Radi se o pogreški nevezivanja prijedloga uz zamjenicu („od mene“). Pogreška nevezivanja prijedloga uz zamjenicu događa se u govoru, no ona je ili gotovo nečujna ili je nevažna jer se radi o novoj misli koja je vezana logičkom stankom. Izgovornih mana nema, a dikcija je umjerena i srednja. Logičko isticanje je dobro, gotovo savršeno, a logičke su stanke česte.

Komparativno se može reći da sva tri govornika nemaju neke konkretne pogreške u naglašavanju, najizraženiju dikciju uočavamo kod Kolinde Grabar-Kitarović, no umjerenu dikciju s možda najugodnijom kontrolom glasa ima Milanović. Logičko isticanje Ive Josipovića je čitalačko i neugodno jer teži poetskom izrazu, dok istodobno afektira. S druge strane, previše afektiranog pokazuje i GrabarKitarović i to smijanjem i pjevanjem što djeluje možda primjereno veseloj atmosferi, no svejedno je preglasno i neuobičajeno. Milanović zadržava jednoličan ton, dobro upotrebljava logičko isticanje i nastoji govoriti svakodnevno. Osim Josipovića koji ponekad preslabo izgovara glas „s“, nijedan govornik nema izgovornu manu. Također, Josipovićev glas je jedini, takoreći, manje fonogeničan od ostala dva govornika.

\subsection{Rezultati retoričkog dizajna}

Retorički dizajn govora Ive Josipovića je, kako je navedeno, čitalački je pa već kod prvog slušanja djeluje u realizaciji odveć izražajno. Upravo realizacija koja u težnji k poetičnom postaje afektirana, i to na izvještačen način. Takvom dojmu pridonosi i spor tempo koji, osim što je spor sam po sebi, dodatno ga usporava publika svojim pljeskom i vikanjem te zvižducima. Rečenice su duge i isprekidane, no i sporo izgovorene, a ritam je govora monoton. Josipović je poliglot i upravo to koristi kao svoju vrlinu te u govoru navodi mnogo riječi stranoga podrijetla koje su asimilirane u hrvatski standard. Vokabular je širok te su pokušaji figurativnosti česti i dovoljno ukrašeni. Stil je jednostavan iako se vidi snažna težnja prema elegantnom stilu, no to mu kao govorniku ne uspijeva. Težnja se vidi u čitanju teksta koje zvuči poput čitanja dramskog teksta te tako u svom govoru pomalo stvara i redundanciju koja se ne temelji na suvišnoj količini riječi već na suvišnoj poetičnosti.

Josipović koristi mnoge retoričke figure unutar govora koje su raznovrsne, od tropa i figura misli pa do morfoloških figura i figura odnosa. Koristi metafore, a metaforična sintagma koju ponavlja kroz govor je „festival demokracije“. Također, u dijelu zahvala koristi nabrajanje: „moram zahvaliti, prije svega, svojoj obitelji... (...), zahvaljujem svojim protukandidatima iz prvog kruga kao i protukandidatu iz drugog kruga, gospodinu Milanu Bandiću, na sudjelovanju na ovom festivalu 
demokracije. (...) Zahvaljujem predsjedniku Republike Hrvatske Stjepanu Mesiću...,, također, koristi se figurom nabrajanja u dijelu kada opisuje vrijednosti koje zastupa: „.. po vrijednostima koje zastupamo: demokracija, sloboda, ljudska prava, pravna država, prava nacionalnih manjina, vjerske slobode, razvijeno gospodarstvo i poduzetništvo, radnička i socijalna prava, kultura, obrazovanje, znanost i ekologija, neke su od najvažnijih postavki...".

Unutar figure nabrajanja postiže i retoričku skromnost spomenom tadašnjega predsjednika Stjepana Mesića, unatoč tomu što je Josipović taj koji je izabran, koristeći njegovu funkciju kao sadašnjost, čime nastoji iskazati skromnost i divljenje.

Uz metaforu „festivala demokracije“ koristi i proširenu metaforu, alegoriju u dijelu: „bili smo velik i dobro usklađen orkestar koji je uvježbao i, danas premijerno, izveo veliku pobjedničku simfoniju. Repriza će biti za pet godina." Metafora je glazbenog diskursa što je prikladno njegovom drugom pozivu kompozitora. Koristi i prozopopeju kao figuru misli u izrazu: „služit ću vama, služit ću Hrvatskoj!“, gdje Hrvatsku antropomorfizira kao osobu kojoj se služi. Od figura riječi ne izostavlja pleonazam: „ponovno vam ponavljam“ koji uistinu zvuči krivo i zaliho. Isto tako, izražena je i figura odnosa ja - mi: „to sam obećao, to ćemo ostvariti!“, kojom je pokušao naglasiti jedinstvo u radu, bez obzira na to što je to samo njegovo obećanje u kampanji. Figuru odnosa izveo je i unutar rečenice: „svaki građanin ove zemlje večeras je pobjednik!“, gdje množinu mijenja jedninom te je poistovjećuje sa svojim likom i djelom, no upravo se unutar te rečenice može vidjeti i hiperboličnost i metonimija.

Tijekom cijeloga govora uz široki vokabular kao pojačivač efekta Josipović koristi makrologiju, odnosno retoričku opširnost koja, ipak, ne stvara toliko sklada kako bi se očekivalo.

Retorički dizajn Kolinde Grabar Kitarović vidljivo je i čujno afektiran puno jače nego što je to bilo kod Josipovića. Tako afektiran govor može biti posljedica adrenalina no, na trenutke, je toliko naglašen da je gotovo travestiran i potpuno je jasno da se afektivnost u govoru Grabar-Kitarović uopće ne drži pod kontrolom. Uz afektivnost, ton glasa je automatski viši od normalnoga unatoč mikrofonima koji omogućuju nadglasavanje publike. Tempo govora je umjeren s također puno stanki koje su opet nastale zbog prekidanja publike, no puno je brži od tempa Ive Josipovića. Ritam je donekle brži, što je možda i posljedica kraćih rečenica koje su jednostavne i nisu nagomilane višesložnim riječima. Izbor riječi je, opet, jednostavan s ne toliko čestim metaforama, a vokabular nije pretjerano širok te se koriste riječi konvencionalnog govora. Poetičnost je izražena u neverbalnoj komunikaciji, no ne i toliko u verbalnoj.

Od figura nije toliko koristila metaforu, no ipak postoji u dijelu zahvale obitelji: „kako su me nosili“, te u komentiranju kampanje: „ova naša utrka“. Od figura misli koristila je retoričko pitanje: „pitali su me: što to tebi treba?" koje je ujedno i upravni govor, ali i sintaktička figura. Često je upotrebljavala hiperbole poput: „veličanstvena noć“, „dragom Hrvatskom“. Te je pridjeve naglašavala snažno i diktivno pa im još više dala na važnosti i zvuku. Kombinirala je prozopopeju i metaforu u dijelu: „Idemo Hrvatsku odvesti u blagostanje!“ gdje je, poput Josipovića, antropomorfizirala Hrvatsku te ju predstavila kao biće. Svakako je u toj rečenici i morfološka figura „mi“ odnos kojim pokušava naglasiti zajedništvo.

U govoru su prisutne i sintaktičke figure poput inverzije: „to Vam obećajem, ovdje, večeras!“, ali i morfološke i tvorbene figure: „dosta je mojih i njegovih, svi ste vi moji!“, u kojima su promijenjene množine i jednine. Još jedna morfološka figura u kojoj se mijenja jednina umjesto množine, ali i u kojoj je prisutna metonimija je: „hvala svakom ribaru, seljaku..“, u kojoj koristi jedninu za sve sektore. Metonimiju koristi i u: „pazili na svaku kunu, svaku lipu“, a jedna od jasnih figura misli, 
koju je poslije kopirao i Milanović, je pretericija: „ne, ne, nemojte, molim vas!“, kojom nastoji smiriti publiku koja zviždi na spomen protukandidata Ive Josipovića, Milana Kujundžića te Ivana Vilibora Sinčića i kojom postiže i retoričku skromnost te se predstavlja kao obrana protukandidata i ona koja će ujediniti sve. Riječ „hrvatsko, hrvatski, Hrvatska“ često se protežu kroz njezin govor pa tako i postiže pleonazam izjavom: „život hrvatskih ljudi u Hrvatskoj“, koji je pomalo uvredljiv. Uvredljivi dio tog pleonazma je kontekst, jer Grabar-Kitarović govori o tome kako se u kampanji napokon usredotočila na ono što je važno, a to je „život hrvatskih ljudi u Hrvatskoj“ i upravo dio „hrvatskih“ je uvredljiv jer u Hrvatskoj ne žive samo Hrvati. Govor je poprilično imperativan i pun je takvih izraza: „dosta je“, „idemo“, „to vam obećajem“ i sl.

Retorički dizajn Zorana Milanovića zanimljiv je i gotovo onakav kakav treba biti. Kombinira poetsko i afektivno, gdje afektivnost kontrolira i ne dopušta si prijeći crtu preemocionalnog izražavanja. Rečenice se unutar govora duže no nisu monotone jer su dovoljno ukrašene figurama. Vokabular je širok, no izbor riječi nije neprikladan i dovoljno je i raznolik i jednostavan kako bi bio shvatljiv svakom slušatelju. Ritam je sukladan tematici, nije prespor niti brz, a stanke nisu česte i publika ne prekida govornika toliko često koliko je prekidala u govorima Grabar-Kitarović i Josipovića. Tempo je umjeren, primjeren atmosferi i okolini, a logičkih stanki unutar rečenica ima toliko koliko je potrebno kako bi se postigla figurativnost govora. Stil nije elegantan, više je „bontonski“ i slavljenički, na trenutke ima i humornih dijelova kojima nasmijava publiku, ali sveukupan je dojam težnje prema elegantnom stilu baš zbog pravilne izražajnosti.

Afektivni izraz potiče tropima i argumentacijom, a intenzitet govora gradi na jakim izrazima, metaforama i visokom intonacijom pri novoj misli. Ujedno, kombinira poetski izraz harmonijom i rečenicama koje se nadovezuju jedna na drugu te se stvara dojam da zna što će reći i kako će reći. Koristi modalni izraz „ponovit ću“ čime je jasno da se pokušava prisjetiti sljedeće misli, što opet dokazuje kako mu govor nije čitalački i kako vjerojatno sve upute, koje je zasigurno dobio, ima već u glavi i ne služi se pomoćnim vizualnim tekstom poput njegovih prethodnika. Od figura koristi metafore: „mjesto pod suncem, mjesto na cesti“, „,veće poluge vlasti“, a upravo prva sintagmatska metafora kojom efektno otvara svoj govor je "tvornica pobjeda“ čime aludira na mjesto održavanja pobjedničkog govora, Tvornicu kulture. I već na početku koristi pretericiju: „ne, ne, ne, ne. Ne i ne! Ovo smo doživjeli jednom na inauguraciji prije pet godina i nikad više. Govorio sam o zviždanju, dakle, to ne radimo. "Na ovakav način kao da istodobno postiže i retoričku skromnost i retoričku oholost.

Koristi poslovicu kao figuru: „istina je jako često u oku promatrača“ kojom pokušava ograditi i sebe, no i pokazati kako nije sve onako kako se prikazuje. Odmah nakon poslovice koristi ponavljanje koje je česta figura unutar Milanovićeva pobjedničkog govora: „brojke su brojke, ali dojam je dojam. $\mathrm{Na}$ tom su primjeru već su vidljive tri retoričke figure $\mathrm{u}$ jednoj i anafora i epifora i simploka. Poslije tijekom govora koristi i ponavljanje simbola: „dah po dah, osmijeh po osmijeh, događaj po događaj.“

Koristi i metonimiju: „da budem uho za svakoga, baš tako, uho i glava za svakoga, a manje rame za plakanje.“, a retoričkom skromnosti navodi: „... različitih predrasuda na koje ni sam nisam imun jer sam obično ljudsko biće. " Nabrajanjem nastoji potkrijepiti argumentaciju da će se ponašati jednako kako se i ponašao kao premijer: „govorit ću, pitat ću, tražit ću, sugerirat ću, davat ću prijedloge...“ no u istoj rečenici koristi paradoks „nadam se da neću iznevjeriti povjerenje koje ste mi dali“, što, ponovno, ima doticaj retoričke skromnosti. Koristi strane riječi unutar govora u rečenici: „neće biti tajnih dealova“, gdje deal označava tajne dogovore kojima aludira na nezakonitost. 


\subsection{Rezultati argumentacije}

Ivo Josipović svoju vjerodostojnost gradi na $\log o s u$, razumnom dijelu, što je vidljivo i iz izbora riječi unutar govora, a patos pokušava izgraditi kroz glazbene metafore. Naime, vjerodostojnost koju ima kao govornik je već temeljena na ekstrinzičnom etosu i na njegovim akademskim zvanjima te poslovima koje je obavljao prije funkcije predsjednika te se to, zapravo, može reći za sve kandidate. Ipak, pokušaj gradnje patosa putem figurativnosti svog drugog zvanja, kompozitora, te navođenja publike da ga shvati kao čovjeka koji nije samo pravnik već i umjetnik te da je i tako blizu emocijama koliko je blizu i razumu.

Tijekom svoga govora Josipović više obećava nego što potkrjepljuje te samo navodi obećanja u kampanji koje ne potvrđuje ničim konkretnim te često koristi glagole poput „vjerujem“, „nadam se“, „smatram“, kojima samo nadopunjuje obećanja i radi svojevrsno ograđivanje. Kao i svaki govor i pobjednički govor Ive Josipovića ima svoje argumentacijske pogreške, stoga su njegove argumentacijske pogreške prikazane u tablici 7.

Tablica 7. Argumentacijske pogreške Ive Josipovića

\begin{tabular}{|c|c|c|}
\hline \multicolumn{3}{|c|}{ Ivo Josipović } \\
\hline Vrsta argumentacijske pogreške & Citat & Min. \\
\hline $\begin{array}{l}\text { Argumentum ad absurdum } \\
\quad \text { (poziv na ruganje) }\end{array}$ & $\begin{array}{l}\text { „Posebno se obraćam onim } \\
\text { građanima koji nisu glasali za mene, } \\
\text { želim biti i njihov predsjednik!“ }\end{array}$ & $00: 01,50$ \\
\hline $\begin{array}{l}\text { Argumentum ad populum } \\
\text { (dokaz koji se ne oslanja } \\
\text { na činjenice i razloge) }\end{array}$ & $\begin{array}{l}\text { „bit ću i vaš predsjednik jer ne želim } \\
\text { razdvajati, želim spajati.“ }\end{array}$ & $00: 02,04$ \\
\hline $\begin{array}{c}\text { Argumentum ad passiones } \\
\text { (emocije) }\end{array}$ & $\begin{array}{l}\text { „stojim ovdje pred svima vama, bez } \\
\text { obzira za koga ste glasovali i kažem: } \\
\text { služit ću vama, služit ću Hrvatskoj!“ }\end{array}$ & $00: 02,10$ \\
\hline $\begin{array}{l}\text { Argumentum ad utile } \\
\text { (obećavanje) }\end{array}$ & $\begin{array}{l}\text { „Davajući mi glas na ovim izborima } \\
\text { prepoznali ste potrebu da se odlučno } \\
\text { i beskompromisno borimo protiv } \\
\text { korupcije organiziranog kriminala, } \\
\text { to sam obećao, to ćemo ostvariti!! }\end{array}$ & $00: 06,16$ \\
\hline
\end{tabular}

Izvor: izradile autorice rada

U tablici 7. može se vidjeti da je Ivo Josipović koristio četiri argumentacijske pogreške: pogreške poziva na ruganje, ulagivanja, sućuti i obećavanja. Od svih argumentacijskih pogrešaka, najnespretnije su prva i druga kojima se pokazala i hladnoća i nesuvislost samih rečenica. Potpuno je jasno da je izabrani predsjednik ujedno predsjednik svih građana, i koliko god se to metaforično nastojalo prikazati, zvučalo je pomalo degradirajući i neuvjerljivo.

Kolinda Grabar-Kitarović svoju vjerodostojnost gradi na patosu, emocionalnoj strani, upotrebljava posvojne pridjeve uz imenicu "Hrvatska“ te pokušava ostvariti temelj svoga govora na veličanju domoljublja, zajednice i obitelji. Publika je tijekom govora interaktivna, a očita je i jaka angažiranost predsjednice koja i kroz neverbalnu i kroz verbalnu komunikaciju nastoji doći do povratne informacije. 
Svojom afektiranošću gradi i argumentaciju, smijeh i pjevanje, iako nepraktične i neobične kao vrste argumentiranja, u ovom se slučaju moraju uzeti u obzir. Naime, pjevanjem domoljubnih pjesama i glasnijim smijanjem, kojima reagira na odobravanje publike, pokušava upravo potvrditi njihovo odobravanje i učiniti to manje službenim.

Grabar-Kitarović se također služi obećavanjem i predstavlja se kao vizionar, onaj koji će Hrvatsku odvesti u svijetlu budućnost tako da koristi superlative unutar sintagme „najrazvijenija država“ te pozitivne pridjeve uz imenicu „domovina“. Slijedi tablični prikaz argumentacijskih pogrešaka korištenih u govoru Kolinde Grabar-Kitarović:

Tablica 8. Argumentacijske pogreške Kolinde Grabar-Kitarović

\begin{tabular}{|c|c|c|}
\hline \multicolumn{3}{|c|}{ Kolinda Grabar-Kitarović } \\
\hline Vrsta argumentacijske pogreške & Citat & Min. \\
\hline \multirow[t]{2}{*}{$\begin{array}{l}\text { Argumentum ad utile } \\
\text { (obećavanje) }\end{array}$} & $\begin{array}{c}\text { „jer bit će Hrvatska među } \\
\text { najrazvijenijim zemljama Europske } \\
\text { unije i svijeta, to vam obećajem, } \\
\text { ovdje, večeras!“ }\end{array}$ & 00:05,07 \\
\hline & $\begin{array}{c}\text { "Ja ću biti vaš glas i vaša } \\
\text { predsjednica!" }\end{array}$ & $00: 09,37$ \\
\hline \multirow{2}{*}{$\begin{array}{l}\text { Argumentum ad populum } \\
\text { (dokaz koji se ne oslanja } \\
\text { na činjenice i razloge) }\end{array}$} & $\begin{array}{l}\text { „drugom domovinom hrvatskoga } \\
\text { naroda, Bosnom i Hercegovinom, i u } \\
\text { Srbiji i u Crnoj Gori.“ }\end{array}$ & $00: 08,50$ \\
\hline & $\begin{array}{l}\text { „Htjela bih večeras zahvaliti svim } \\
\text { kandidatima... (...) svi mi želimo } \\
\text { bolju Hrvatsku.“ }\end{array}$ & $00: 10,07$ \\
\hline $\begin{array}{c}\text { Petitio principi } \\
\text { (zahtijevanje počela ili } \\
\text { moljenje pitanja) }\end{array}$ & $\begin{array}{c}\text { „I ova naša utrka, ovaj naš program, } \\
\text { ovo što smo radili do sada, sve je } \\
\text { to dovelo do toga da se konačno } \\
\text { usredotočimo na ono što je bitno, } \\
\text { život hrvatskih ljudi u Hrvatskoj, } \\
\text { život naših iseljenika, život Hrvata } \\
\text { u BiH.." }\end{array}$ & $00: 10,08$ \\
\hline
\end{tabular}

Izvor: izradile autorice rada

U tablici 8. vidljivo je da Grabar-Kitarović nosi tri vrste argumentacijskih pogrešaka: ulagivanje publici, argument obećavanja i cirkularni silogizam koji ne potkrjepljuje ni na jedan način. U dva slučaja koristi tzv. ulagivanje kojim nastoji pridobiti publiku koja nije glasovala za nju i glasače u susjednim zemljama. Također, u dva navrata upotrijebila je argument obećavanja, a jednom je upotrijebila cirkularni silogizam.

Zoran Milanović vjerodostojnost gradi intrinzičnim etosom i to tako da miješa i ekstrinzično, a to je da spominje svoju prijašnju funkciju premijera koja je relevantna i kojom obznanjuje da već zna kako se ponašati. Unutar svoga govora radi kombinaciju etosa, patosa i logosa i to ne radi loše. Naime, etos, kako je već navedeno, gradi i intrinzično i ekstrinzično, dok patos gradi uz emocionalne izjave, ali i humor, spominjući zabavu uz oprez („nije najava prohibicije“) te uz poslovične rečenice kako 
je on samo „obično ljudsko biće“. Svakako logos gradi oprezno i dobro i to pozivajući se na Ustav, državni ustroj i zakone. Naglašava kako Ustav jako dobro poznaje i zna što predsjednik može, a što ne smije. Također, kao Grabar-Kitarović, argumentira kroz izraze, ali u njegovom slučaju poetski ističući važnije govorne dijelove promjenom ritma i logičkim stankama. Argumentacijske pogreške Zorana Milanovića prikazane su u tablici 9.

Tablica 9. Argumentacijske pogreške Zorana Milanovića

\begin{tabular}{|c|c|c|}
\hline \multicolumn{3}{|c|}{ Zoran Milanović } \\
\hline Vrsta argumentacijske pogreške & Citat & Min. \\
\hline $\begin{array}{c}\text { Petitio principi } \\
\text { (zahtijevanje počela ili } \\
\text { moljenje pitanja) }\end{array}$ & $\begin{array}{l}\text { „Borio sam se za istinu, mada istina } \\
\text { je vrlo često u oku promatrača.“ }\end{array}$ & $00: 02,38$ \\
\hline $\begin{array}{c}\text { Argumentum ad misericordium } \\
\text { (sućut) }\end{array}$ & $\begin{array}{l}\text { „.. na koje ni sam nisam imun jer } \\
\text { sam obično ljudsko biće." }\end{array}$ & $00: 03,46$ \\
\hline $\begin{array}{l}\text { Argumentum ad utile } \\
\text { (obećanje) }\end{array}$ & $\begin{array}{l}\text { „Neće biti zaplotnjaštva, neće biti } \\
\text { spletki, neće biti tajnih dealova i } \\
\text { poslova. Za mene će, dopalo se to } \\
\text { svima ili ne, sve stranke na onoj } \\
\text { formalnoj zakonskoj razini biti iste.“ }\end{array}$ & $00: 05,37$ \\
\hline $\begin{array}{c}\text { Argumentum ad baculum } \\
\text { (prijetnja) }\end{array}$ & $\begin{array}{c}\text { „Sve drugo je put u autokraciju, } \\
\text { tiraniju, samovolju, otimačinu i } \\
\text { predsjednik Republike tome mora } \\
\text { biti brana.“ }\end{array}$ & 00:06,04 \\
\hline
\end{tabular}

Izvor: izradile autorice rada

U tablici 3.3.3. vidljivo je da Milanović radi četiri argumentacijske pogreške: cirkularni silogizam, argument sućuti, obećanja i prijetnje. Posljednja pogreška nije tipična prijetnja, već ljepše sročena, no ipak nespretna zbog izbora riječi i imenica koje su prestroge za takav govor.

Smisao i smjer sadržaja sva tri govora je drugačiji, Grabar-Kitarović i Josipović drže se iste niti vodilje, a to su obećanja o boljitku RH. Ipak, Josipović je usredotočen na pravni aspekt, konkretnije na smanjenje stope kriminala, suzbijanje kriminala, a najvažniji pridjev unutar njegova govora je „pravna (država)“. Kod Kolinde Grabar-Kitarović ponešto je drugačije jer se ne bazira na konkretnim trenucima i stavkama za budućnost Hrvatske, već na općenitom naglašavanju važnih vrijednosti i viđenja Hrvatske kao prosperitetne države Balkana i Europske unije. Milanović, pak, ima potpuno drugačiji tijek govora. Temelji ga na univerzalnostima, spominjući višestranačku parlamentarnu demokraciju i Ustav na kojem je utemeljena država. Važno je naglasiti da nijedan govor nije tipičan govor s određenim dijelovima argumentacije jer se ne radi o tipičnim raspravama, no svakako mora imati potkrjepe i praktične argumente kojima bi opravdao svoj izabrani status. Kolinda GrabarKitarović cijelo vrijeme potiče publiku na interakciju spominjanjem pokojnog predsjednika dr. Franje Tuđmana, što je radio i Ivo Josipović sa spominjanjem Stjepana Mesića, no ta je interakcija publike na istu taktiku kod Grabar-Kitarović znatno drugačija. Argumentacija svih govora, iako ne u količini koliko je imaju govori gdje postoje sugovornici, postoji. Bez obzira na argumentacijske pogreške koje su prisutne u gotovo svim govorima, svejedno je suvisla i upotpunjena je, više i manje emocionalnom i racionalnom vjerodostojnošću. 


\section{Zaključak}

Glavni cilj istraživanja bio je odrediti krucijalne razlike i sličnosti u govornoj izvedbi, retoričkom dizajnu, argumentaciji pobjedničkih govora posljednja tri hrvatska predsjednika. Nastojalo se odrediti na koje faktore i vještine govorne izvedbe, znanja o retorici i argumentiranju bi trebalo obratiti pažnju kada se radi o javnoj komunikaciji, odnosno o govorima ove vrste na predsjedničkim funkcijama. Znanje i teorijsko razumijevanje nije dovoljno i jasno je da se može poznavati svaki aspekt teorije i filozofije retorike, ako se u praksi ne uključe vještine koje je, ipak, potrebno konstantno uvježbavati. U dijelu govorne izvedbe potrebno je paziti na zdravlje govornoga aparata, vježbati glas i izgovor, kontrolirati tempo i ritam te postizati čvrstinu i stabilnost glasa, a u dijelu retoričkog dizajna i argumentiranja potrebno je logički razumjeti ono što se govori, uključiti sposobnost rasuđivanja, poznavati strukturu govora i najvažnije, sve suvislo argumentirati.

Rezultati istraživanja potvrdili su sve tri hipoteze. Prozodija, naglasni sustav, u sva tri govora nije bio $\mathrm{u}$ velikoj mjeri pogrešan, odnosno otklona je bilo minimalno i nisu u fokusu i pažnji slušatelja, stoga je prva hipoteza potvrđena. Također, najbolji izgovor riječi kada se govori o naglascima, pokazao se u govoru Ive Josipovića. Druga hipoteza je također potvrđena pa se može reći da je svaki govornik, uz metaforu, koristio niz retoričkih figura poput pretricije, retoričke opširnosti, retoričke skromnosti i oholosti, simploke, anafore, epifore, hiperbole, metonimije i slično. Isto tako, Ivo Josipović i Zoran Milanović imali su četiri argumentacijske pogreške, a Kolinda Grabar-Kitarović tri, čime je potvrđena i treća hipoteza.

Zaključeno je da se su sva tri govora uvelike razlikuju te da u svakom govoru postoje nedostaci te je nemoguće izabrati govor koji zadovoljava sve kriterije. Govor Ive Josipovića je staložen i konkretan. Govornik raspolaže podacima, iskazuje i referira se na bitne vrijednosti koje su, ujedno, političke univerzalije, no govor nema čvrstinu, glas je mekan i kao da ne priliči funkciji koju obnaša, te sam sadržaj nije dovoljno dobro argumentiran i previše je zasnovan na racionalnom, odnosno gradnji vjerodostojnosti logosom. Govor Kolinde Grabar-Kitarović previše je pak zasnovan na emocionalnosti i afektiranju. Argumentacija je također provedena afektivnim izrazom, a govor, za razliku od Josipovićeva, nosi emocionalne vrijednosti, i zasniva se na patosu. Glas je u normalnim uvjetima fonogeničniji i ugodniji, govori artikulativno, no glas puca, ponesen atmosferom i ponekad graniči s vikanjem. Najbolju gradnju vjerodostojnosti imao je Milanović s dovoljnim logičkim izrazom i kontrolom afektiranja i poetike postigao je dojam akumena. Ipak, argumentacijskih pogrešaka ni u njegovom slučaju nije manjkalo, no potrebno je naglasiti da je jedini vodio govor bez tekstualnih pomagala, odnosno bez prethodno napisanih uputa. Isticanje je dobro, glas nije potpuno fonogeničan no nije ni neugodan, fluentnost je posebno uočljiva, a govor je prožet jednostavnim rječnikom, a korištene tuđice ili stručne termine pobliže objašnjava.

Retorika i umijeće modernog javnog govora tema su razmatranja i istraživanja brojnih stručnjaka te su se upravo na govorima velikih državnika uspostavljale koncepcije tih teorija. Svaka struja teoretiziranja modernog govorništva ipak ima slične ciljeve dobroga govora, a to je povratna informacija publike, dojam koji govornik ostvaruje pomoću kompetencija, vještina i znanja.

Naposljetku, znanja normativa nekad nisu dovoljna nego i već urođene osobine mogu biti presudne, poput boje glasa, čvrstine govora, pa i neverbalne komunikacije koja mora djelovati prirodno. Uz navedeno svakako treba istaknuti i suvisli sadržaj sa samostalno ugrađenom dozom empatije koja nosi emocionalnu stranu svakoga govora. Nikako se ne smiju zaboraviti figure koje potpomažu u oslikavanju govora, boljem razumijevanju, ugradnji ideje ili izgrađivanju vjerodostojnosti. Ipak, ne postoji savršena interpretacija i realizacija govornoga teksta, unatoč preporučenim mehanizmima struke, no važno ju je nadograđivati, uvježbavati i readaptirati ovisno o situaciji, pogotovo treba o njoj kritički razmišljati kada su u pitanju poznati govornici. 


\section{Literatura}

Anić, V. (2006). Veliki rječnik hrvatskoga jezika. Znanje.

Biočina, Z. (2015). Analiza govora hrvatskih zastupnika u Europskom parlamentu. Govor, 32(2), 155-179.

Borg J. (2010). Moć uvjeravanja. Veble commerce.

Borčić, N. (2009). Kontrastivna analiza tekstne vrste politički intervju s obzirom na rodne osobitosti. Neobjavljeni znanstveni magistarski rad. Sveučilište u Zadru.

Borčić, N. (2010). Konceptualne metafore u političkim intervjuima. Medijske studije, 1(1-2), 136-155.

Čerepinko, D. (2011). Komunikologija: kratki pregled najvažnijih teorija, pojmova i principa.

Veleučilište u Varaždinu.

Govor predsjednika: Zoran Milanović - „Budimo jedinstveni u različitosti, osmijeh po osmijeh“,

Preuzeto s: https://www.youtube.com/watch?v=2QluZ5MW6uE

Ivo Josipović - treći hrvatski predsjednik - pobjednički govor.

https://www.youtube.com/watch?v=J3If-1VE-hI

Kišiček, G. i Stanković, D. (2014). Retorika i društvo. Naklada Slap.

Kišiček, G. (2010). Pogreške u argumentaciji - dvojbe u tumačenju i klasifikaciji. Govor, 27(2), 129-143.

McNair, B. (2003). Uvod u političku komunikaciju. Fakultet političkih znanosti.

Lucas, S.E. (2015). Umijeće javnoga govora. MATE d.o.o.

Pavličević-Franić, D. (2008). Jezične i nejezične sastavnice govora. Jezik - Časopis za kulturu hrvatskog književnog jezika, god. 55(2), 41 - 80.

Pobjednički govor Kolinde Grabar-Kitarović, https://www.youtube.com/watch?v=1rrfMS5bYCg

Škarić, I. (2011). Argumentacija. Nakladni zavod Globus.

Škarić, I. (2000). Temeljci suvremenog govorništva. Školska knjiga d.d.

Škarić, I. i Varošanec-Škarić, G. (1994). Skupna slika govora Hrvatske radiotelevizije, Govor, 11(2), 1-14.

Škarić, I. (1995). Odlike hrvatske državne medijske govorničke škole. Govor, 12(1)., 33 - 46.

Škarić, I. (1981). Poetsko i afektivno u govoru. Umjetnost riječi, br. 2.

Tomić, Z., Jugo, D., Radalj, M. (2020). Javna komunikacija, Hum: časopis Filozofskog fakulteta

Sveučilišta u Mostaru, 15(23), 7-37. 


\title{
Analysis and comparison of verbal communication of winning speeches of the last three Presidents of the Republic of Croatia
}

\author{
STANA ODAK KRASIĆ \\ VERN' University, Zagreb
}

VALENTINA PAVLOVIĆ

VERN' University, Zagreb

\begin{abstract}
Public speaking of statesmen has always been the focus of analysis and a topic of discussion for the experts, citizens and the media, especially when it comes to public communication of the highest state officials. Modern oratory and public communication theories are in the state of constant change and new technologies are rapidly leading this discipline towards novelties but, at the same time, they keep reminding us to uphold standards and usual practices. An analysis of verbal communication of heads of state is often the main core of research in which authors seek to detect deviations from and adherence to standards in the speeches but also, they try to compare the same speeches using comparative analysis by which they try to identify the distinctions and similarities. The topic of this research is an analysis of verbal communication of the winning speeches of the last three presidents of the Republic of Croatia and in this research, the main goal is to compare and analyze the content of the speeches. The paper concludes that each of the speeches has its flaws and imperfections but also that each speaker demonstrates advantages and each one of them implemented skills and knowledge into their speech.
\end{abstract}

Keywords: analysis, verbal communication, president of the Republic of Croatia, the winning speech 